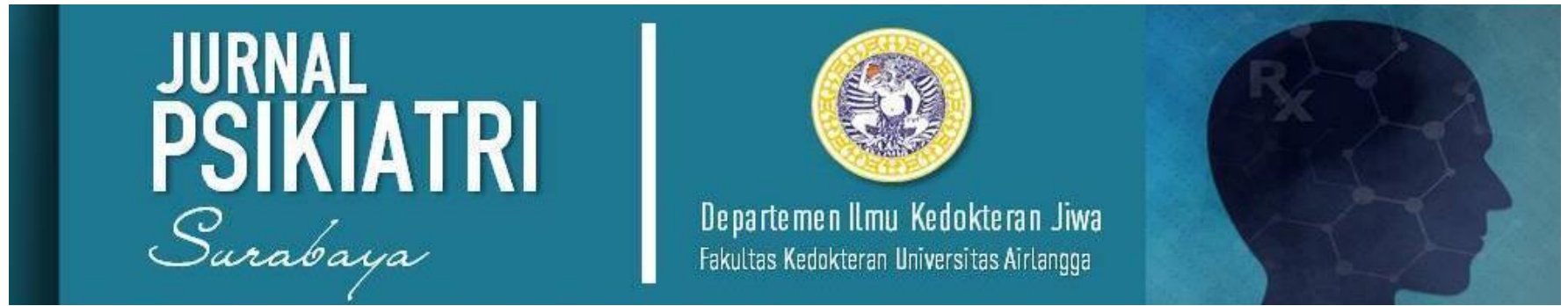

\title{
Articles
}

\section{Association Between Residence and Disease Incidences in The Dr. Soetomo Hospital Psychiatric Clinic}

\author{
Firda Fauziah Hidayat ${ }^{1}$, Khairina ${ }^{1}$, Budi Utomo ${ }^{2}$
}

\begin{abstract}
${ }^{1}$ Departement of Psychiatry, Faculty of Medicine, Universitas Airlangga/ Dr. Soetomo Hospital, Surabaya, Indonesia ${ }^{2}$ Departement of Public Health-Preventive Medicine, Faculty of Medicine, Universitas Airlangga/ Dr. Soetomo Hospital, Surabaya, Indonesia
\end{abstract}

\section{OPEN}

\section{ACCESS}

\section{ARTICLE INFO}

Received: November 2, 2020 Revised: November 27, 2020 Accepted: November 30, 2020 Published: November 1, 2021

*) Corresponding author:

E-mail: firda.fauziah.hidayat2017@fk.unair.ac.id

Keywords:

Disease incidences,

Dr. Soetomo

hospital, Mental

disorder, Patients'

residence, Surabaya

City

This is an open access article under the CC BY-SA license (https://creativecommons.org/lic enses/by-sa/4.0/)

\begin{abstract}
The increasing mental disorders prevalence adds countries' burdens. One of the mental disorder's risks is residence. There is no research about the relationship between residence and ten most psychiatric diseases in Surabaya. This research aims to study the relationship between residence and ten most diseases in Dr. Soetomo hospital psychiatric clinic. This research method using observational-analytic design with a cross-sectional approach in Dr. Soetomo hospital psychiatric clinic. Data were taken from medical records based on inclusion and exclusion criteria. The research used a chi-square test with $95 \%$ CI. The dominant districts where research subjects lived were education-related psychiatric examinations in Semampir, paranoid schizophrenia in Sawahan, mental disorders due to brain damage in Sawahan, moderate depressive episodes in Gubeng, MMR in Kenjeran, activity and behavior disorders in Sawahan, hebefrenic schizophrenia in Tambaksari, family-related psychiatric examinations in Tambaksari, atypical autism in Sukomanunggal and Semampir, MADD in Tambaksari. Distribution of patients' residence based on five regions of Surabaya was East Surabaya as the dominant residence of paranoid schizophrenia, moderate depressive episodes, hebephrenic schizophrenia, atypical autism, MADD; North Surabaya as the dominant residence of education-related psychiatric examinations, MMR; South Surabaya as the dominant residence of paranoid schizophrenia, mental disorders due to brain damage, activity and behavior disorders, family-related psychiatric examinations. Chi-square test showed a significant relationship between residence and ten most diseases. There is a significant (goodness of fit) relationship between residence and ten most diseases in Dr. Soetomo hospital psychiatric clinic.
\end{abstract}

Cite this as: Hidayat, F. F., Khairina., Utomo, B. “Association Between Residence And Disease Incidences In the Dr. Soetomo Hospital Psychiatry Clinic”. Jurnal Psikiatri Surabaya, vol. 10, no. 2, pp.57-66, 2021, doi: 10.20473/jps.v10i2.22945. 


\section{Introduction}

The increasing number of mental disorders has significantly increased countries' burdens [1]. The mental disorders prevalence in Indonesia increased from $1.7 \%$ to $7 \%$ [2]. Previous studies have shown that residence influences the mental disorders' incidence [3]. However, there are not many studies that discuss the residence factor in ten most mental disorders in Surabaya.

Residence factors such as population density, industrial areas, poverty levels, and education also contribute to mental disorders. This research aims to examine the distribution and to analyze the relationship between residence and ten most diseases in the Dr. Soetomo Hospital Psychiatry Clinic July 2017 - June 2019 who resides in Surabaya. This research is expected to be used as a reference to reduce the mental disorders' incidence in Surabaya.

\section{Methods}

This is an observational analytic study with a retrospective cross-sectional approach. Sampling was done by purposive sampling technique, with $\alpha=0.05$ $\left(\mathrm{z}_{\alpha}=1.96\right)$ and a population deviation of $5 \%$. The minimum sample size was calculated using the Lemeshow formula, obtained a sample of 384.16 [4].
The study inclusion criteria were patients residing in Surabaya and patients diagnosed included in ten most diseases at Dr. Soetomo Hospital psychiatry clinic. The study exclusion criteria were medical records that did not contain the patient's diagnosis and residence. The data used from secondary data, namely electronic medical records. This research was conducted by analyzing patient data from Dr. Soetomo Hospital for the period $1^{\text {st }}$ July 2017 to $30^{\text {th }}$ June 2019.

\section{Results}

Research data processing by grouping the patient's diagnosis based on ICD-X and sorted into the ten most diseases using Ms. Excel. Data were analyzed using SPSS version 26 for windows with the chi-square test (goodness of fit) with a $95 \% \mathrm{CI}(\alpha=0.05)$. The number of patients in two years was 3,687 patients and based on the inclusion and exclusion criteria of the research, a sample of 1,294 research subjects was obtained with 20 study subjects who had 2 diagnoses including the ten most diseases. There were 2,356 patients excluded because their diagnosis were not included in the ten most diseases, 36 patients were excluded because they did not live in Surabaya and 1 patient was excluded because his address was not listed in the medical record. The ten most diseases were obtained from 313 diseases recorded in the Dr. Soetomo Hospital psychiatric clinic.

Table 1. Distribution of disease incidence per district in Surabaya

\begin{tabular}{lcccccccccc}
\hline Kecamatan & Z55/.8 & F20.0/.04 & F06.8 & F32.1 & F70 & F90.0 & F20.1 & Z63.7 & F84.1 & F41.2 \\
\hline 1. Tegalsari & 21 & 16 & 2 & 3 & 7 & 2 & 1 & 1 & 3 & 1 \\
\hline 2. Simokerto & 12 & 6 & 1 & 2 & 5 & 6 & 1 & 4 & 0 & 0 \\
\hline 3. Genteng & 8 & 2 & 1 & 2 & 0 & 3 & 2 & 0 & 3 & 1 \\
\hline 4. Bubutan & 17 & 7 & 4 & 4 & 5 & 7 & 2 & 3 & 3 & 0 \\
\hline 5. Gubeng & 23 & 21 & 8 & 15 & 2 & 9 & 2 & 2 & 5 & 5 \\
\hline $\begin{array}{l}\text { 6. Gunung } \\
\text { Anyar }\end{array}$ & 5 & 3 & 4 & 1 & 0 & 0 & 3 & 0 & 1 & 2 \\
\hline 7. Sukolilo & 3 & 6 & 2 & 3 & 0 & 1 & 3 & 1 & 1 & 3 \\
\hline 8. Tambaksari & 43 & 27 & 4 & 10 & 10 & 11 & 9 & 7 & 5 & 7 \\
\hline 9. Mulyorejo & 6 & 3 & 2 & 2 & 2 & 0 & 2 & 1 & 1 & 1 \\
\hline 10. Rungkut & 2 & 4 & 4 & 3 & 0 & 4 & 1 & 1 & 5 & 1 \\
\hline $\begin{array}{l}\text { 11. Tenggilis } \\
\text { Mejoyo }\end{array}$ & 2 & 2 & 1 & 0 & 1 & 0 & 2 & 0 & 1 & 0 \\
\hline 12. Benowo & 1 & 3 & 2 & 4 & 1 & 0 & 0 & 2 & 3 & 0 \\
\hline 13. Pakal & 1 & 1 & 1 & 0 & 1 & 0 & 0 & 0 & 1 & 0 \\
\hline
\end{tabular}


JPS. Volume 10 No 2. Nov 2021 / Association Between Residence and Incidences in the Dr. Soetomo Hospital Psychiatry Clinic

\begin{tabular}{|c|c|c|c|c|c|c|c|c|c|c|}
\hline 14. Asemrowo & 13 & 3 & 6 & 4 & 6 & 0 & 1 & 3 & 1 & 1 \\
\hline $\begin{array}{l}\text { 15. Sukoma- } \\
\text { nunggal }\end{array}$ & 13 & 4 & 5 & 4 & 6 & 1 & 0 & 4 & 6 & 2 \\
\hline 16. Tandes & 10 & 5 & 6 & 1 & 1 & 2 & 3 & 1 & 2 & 1 \\
\hline $\begin{array}{l}\text { 17. Sambike- } \\
\text { rep }\end{array}$ & 1 & 8 & 0 & 1 & 2 & 1 & 0 & 2 & 0 & 0 \\
\hline $\begin{array}{l}\text { 18. Lakarsan- } \\
\text { tri }\end{array}$ & 4 & 7 & 0 & 0 & 0 & 0 & 1 & 1 & 0 & 0 \\
\hline 19. Bulak & 1 & 2 & 2 & 2 & 3 & 0 & 0 & 1 & 0 & 0 \\
\hline 20. Kenjeran & 31 & 11 & 5 & 7 & 12 & 6 & 2 & 4 & 3 & 1 \\
\hline 21. Semampir & 130 & 9 & 7 & 3 & 8 & 9 & 5 & 4 & 6 & 1 \\
\hline $\begin{array}{l}\text { 22. Pabean } \\
\text { Cantian }\end{array}$ & 8 & 5 & 5 & 0 & 1 & 1 & 4 & 1 & 0 & 1 \\
\hline $\begin{array}{l}\text { 23. Krembang } \\
\text {-an }\end{array}$ & 22 & 7 & 6 & 3 & 7 & 2 & 6 & 5 & 2 & 1 \\
\hline $\begin{array}{l}\text { 24. Wonokro } \\
\text { mo }\end{array}$ & 13 & 17 & 4 & 5 & 2 & 4 & 4 & 4 & 0 & 2 \\
\hline 25. Wonocolo & 2 & 3 & 2 & 3 & 1 & 2 & 1 & 2 & 4 & 0 \\
\hline 26. Wiyung & 4 & 4 & 4 & 2 & 3 & 0 & 1 & 1 & 0 & 1 \\
\hline $\begin{array}{l}\text { 27. Karang } \\
\text { Pilang }\end{array}$ & 3 & 8 & 2 & 1 & 0 & 3 & 3 & 3 & 2 & 2 \\
\hline 28. Jambangan & 3 & 2 & 3 & 1 & 0 & 1 & 1 & 1 & 0 & 2 \\
\hline 29. Gayungan & 0 & 0 & 2 & 1 & 0 & 0 & 0 & 0 & 0 & 1 \\
\hline $\begin{array}{l}\text { 30. Dukuh } \\
\text { Pakis }\end{array}$ & 6 & 3 & 2 & 2 & 0 & 4 & 0 & 2 & 2 & 3 \\
\hline 31. Sawahan & 46 & 29 & 9 & 13 & 5 & 12 & 8 & 4 & 3 & 6 \\
\hline Total & 454 & 228 & 106 & 102 & 91 & 91 & 68 & 65 & 63 & 46 \\
\hline
\end{tabular}

Z55 : Problems related to education and literacy; Z55.8: other problems related to education and literacy; F20.0: paranoid schizophrenia; F20.04: paranoid schizophrenia, partial remission; F06.8: Other mental disorders are determined to result from brain damage and dysfunction; physical illness; F32.1: Major Depressive Disorder (MDD), single episode, moderate; F70: Mild Mental
Retardation

(MMR);

F90.0:

Attention deficit/hyperactivity disorder (ADHD), predominantly inattentive type; F20.1: Hebephrenic schizophrenia; Z63.7: Other stressful life events affecting family and household; F84.1: Atypical autism; F41.2: Mixed Anxiety and Depressive Disorder (MADD).

Table 2. Distribution of disease incidence based on five regions in Surabaya

\begin{tabular}{|c|c|c|c|c|c|c|}
\hline \multirow{2}{*}{\multicolumn{2}{|c|}{ Variable }} & \multicolumn{5}{|c|}{ Residence } \\
\hline & & \multirow[t]{2}{*}{$\begin{array}{c}\text { Central } \\
\text { Surabaya }\end{array}$} & \multirow[t]{2}{*}{$\begin{array}{c}\text { East } \\
\text { Surabaya }\end{array}$} & \multirow[t]{2}{*}{$\begin{array}{c}\text { West } \\
\text { Surabaya }\end{array}$} & \multirow[t]{2}{*}{$\begin{array}{c}\text { North } \\
\text { Surabaya }\end{array}$} & \multirow[t]{2}{*}{$\begin{array}{c}\text { South } \\
\text { Surabaya }\end{array}$} \\
\hline \multicolumn{2}{|c|}{ Diagnosis } & & & & & \\
\hline \multirow{2}{*}{$\begin{array}{c}Z 55 / .8 \\
(n=454)\end{array}$} & $\mathrm{n}$ & 58 & 84 & 43 & 192 & 77 \\
\hline & $\%$ & 12.8 & 18.5 & 9.5 & 42.3 & 17.0 \\
\hline \multirow{2}{*}{$\begin{array}{c}\mathrm{F} 20.0 / .04 \\
(\mathrm{n}=228)\end{array}$} & $\mathrm{n}$ & 31 & 66 & 31 & 34 & 66 \\
\hline & $\%$ & 13.6 & 28.9 & 13.6 & 14.9 & 28.9 \\
\hline \multirow{2}{*}{$\begin{array}{c}\text { F06.8 } \\
(n=106)\end{array}$} & $\mathrm{n}$ & 8 & 25 & 20 & 25 & 28 \\
\hline & $\%$ & 7.5 & 23.6 & 18.9 & 23.6 & 26.4 \\
\hline \multirow{2}{*}{$\begin{array}{c}\text { F32.1 } \\
(n=102)\end{array}$} & $\mathrm{n}$ & 11 & 34 & 14 & 15 & 28 \\
\hline & $\%$ & 10.8 & 33.3 & 13.7 & 14.7 & 27.5 \\
\hline \multirow{2}{*}{$\begin{array}{c}\text { F70 } \\
(n=91)\end{array}$} & $\mathrm{n}$ & 17 & 15 & 17 & 31 & 11 \\
\hline & $\%$ & 18.7 & 16.5 & 18.7 & 34.1 & 12.1 \\
\hline \multirow{2}{*}{$\begin{array}{l}\mathrm{F} 90.0 \\
(\mathrm{n}=91)\end{array}$} & $\mathrm{n}$ & 18 & 25 & 4 & 18 & 26 \\
\hline & $\%$ & 19.8 & 27.5 & 4.4 & 19.8 & 28.6 \\
\hline
\end{tabular}




\begin{tabular}{ccrrrrr} 
F20.1 & $\mathrm{n}$ & 6 & 22 & 5 & 17 & 18 \\
$(\mathrm{n}=68)$ & $\%$ & 8.8 & 32.4 & 7.4 & 25.0 & 26.5 \\
$\mathrm{Z} 63.7$ & $\mathrm{n}$ & 8 & 12 & 13 & 15 & 17 \\
$(\mathrm{n}=65)$ & $\%$ & 12.3 & 18.5 & 20.0 & 23.1 & 26.2 \\
$\mathrm{~F} 84.1$ & $\mathrm{n}$ & 9 & 19 & 13 & 11 & 11 \\
$(\mathrm{n}=63)$ & $\%$ & 14.3 & 30.2 & 20.6 & 17.5 & 17.5 \\
$\mathrm{~F} 41.2$ & $\mathrm{n}$ & 2 & 19 & 4 & 4 & 17 \\
$(\mathrm{n}=46)$ & $\%$ & 4.3 & 41.3 & 8.7 & 8.7 & 37.0 \\
\hline
\end{tabular}

Table 2 shows that most patients with psychiatric examinations related to education live in North Surabaya; Most patients with mental disorders due to brain damage live in South Surabaya; Most patients with MDD live in East Surabaya; Most patients with MMR live in North Surabaya; most ADHD disturbances live in South
Surabaya; most hebephrenic schizophrenics live in East Surabaya; psychiatric examination related to problems in the relationship related to mental disorders / general medical conditions mostly live in South Surabaya; autism is not typical of people living in East Surabaya; MADD mostly lived in East Surabaya

Tabel 3. Research Analysis

\begin{tabular}{|c|c|c|c|c|c|c|c|c|c|c|c|c|c|}
\hline \multirow{3}{*}{ Variable } & \multicolumn{10}{|c|}{ Residence } & \multicolumn{2}{|c|}{ Total } & \multirow{3}{*}{$\begin{array}{c}\mathrm{P} \\
\text { value }\end{array}$} \\
\hline & \multicolumn{2}{|c|}{$\begin{array}{c}\text { Central } \\
\text { Surabaya }\end{array}$} & \multicolumn{2}{|c|}{$\begin{array}{c}\text { East } \\
\text { Surabaya }\end{array}$} & \multicolumn{2}{|c|}{$\begin{array}{c}\text { West } \\
\text { Surabaya }\end{array}$} & \multicolumn{2}{|c|}{$\begin{array}{c}\text { North } \\
\text { Surabaya }\end{array}$} & \multicolumn{2}{|c|}{$\begin{array}{c}\text { South } \\
\text { Surabaya }\end{array}$} & \multirow{2}{*}{$\mathrm{n}$} & \multirow{2}{*}{$\%$} & \\
\hline & $\mathrm{f}$ & $\%$ & $\mathrm{f}$ & $\%$ & $\mathrm{f}$ & $\%$ & $\mathrm{f}$ & $\%$ & $f$ & $\%$ & & & \\
\hline \multicolumn{14}{|l|}{ Diagnosis } \\
\hline Z55/.8 & 58 & 12.8 & 84 & 18.5 & 43 & 9.5 & 192 & 42.3 & 77 & 17.0 & 454 & 100 & \multirow{10}{*}{0,000} \\
\hline F20.0/.04 & 31 & 13.6 & 66 & 28.9 & 31 & 13.6 & 34 & 14.9 & 66 & 28.9 & 228 & 100 & \\
\hline F06.8 & 8 & 7.5 & 25 & 23.6 & 20 & 18.9 & 25 & 23.6 & 28 & 26.4 & 106 & 100 & \\
\hline F32.1 & 11 & 10.8 & 34 & 33.3 & 14 & 13.7 & 15 & 14.7 & 28 & 27.5 & 102 & 100 & \\
\hline F70 & 17 & 18.7 & 15 & 16.5 & 17 & 18.7 & 31 & 34.1 & 11 & 12.1 & 91 & 100 & \\
\hline F90.0 & 18 & 19.8 & 25 & 27.5 & 4 & 4.4 & 18 & 19.8 & 26 & 28.6 & 91 & 100 & \\
\hline F20.1 & 6 & 8.8 & 22 & 32.4 & 5 & 7.4 & 17 & 25.0 & 18 & 26.5 & 68 & 100 & \\
\hline Z63.7 & 8 & 12.3 & 12 & 18.5 & 13 & 20.0 & 15 & 23.1 & 17 & 26.2 & 65 & 100 & \\
\hline F84.1 & 9 & 14.3 & 19 & 30.2 & 13 & 20.6 & 11 & 17.5 & 11 & 17.5 & 63 & 100 & \\
\hline F41.2 & 2 & 4.3 & 19 & 41.3 & 4 & 8.7 & 4 & 8.7 & 17 & 37.0 & 46 & 100 & \\
\hline
\end{tabular}

Table 3 shows the frequency and percentage of patient residences based on five regions in Surabaya City and the incidence of ten most diseases at Dr. Soetomo Hospital psychiatric clinic. The association between place of residence and the incident diagnosis was

\section{Discussion}

Distribution of disease incidence per district in Surabaya

1) Psychiatric examinations related to education and literacy problems (Z55) and psychiatric examinations related to other education and literacy problems (Z55.8) mostly occurred in Semampir, Sawahan, and Tambaksari Districts. In this research, the three districts with the highest number of primary schools also had the highest Z55 and Z55.8 incidence. A large number of schools can analyzed by chi-square test. Place of residence and the incident diagnosis has a p-value of 0.000 which means it is smaller than the value of $\alpha(0.05)$ that show both have a significant relationship (goodness of fit).

increase community participation in obtaining an education. One of the first steps before taking primary school education is to take an education-related psychological exam. This is supported by UNESCO's research that the incidence of illiteracy occurs significantly in densely populated countries, one of which is Indonesia [5].

2) Paranoid schizophrenia (F20.0) and paranoid schizophrenia, partial remission (F20.04) mostly occurred in Sawahan, Tambaksari, and Gubeng Districts. 
In this research, 28 out of 31 districts had a higher incidence of paranoid schizophrenia than other schizophrenia types. This is supported by research in Pontianak that paranoid schizophrenia is the most common schizophrenia [6]. Schizophrenia is associated with congenital infections such as rubella and cytomegalovirus which impaired neuron development.

Risk factors for schizophrenia in adulthood include the herpes virus, Toxoplasma gondii, and Chlamydia [7]. Research is needed on immunization coverage and infection rates against the schizophrenia incidence in Surabaya.

3) Other mental disorders are determined to result from brain damage and dysfunction; physical illness (F06.8) mostly occurred in Sawahan, Gubeng, and Semampir Districts. In this research, F06.8 was included in the ten most diseases with $7.8 \%$ incidence. This is supported by research in a Nepalese prison hospital whose F06.8 is one of the ten most diseases with 2 of 121 inmates (1.7\%) [8]. Research by Block and CalderónGarcidueñas shows that the brain damage incidence is higher in industrial areas with lots of air pollutants [3]. The research result by Block and Calderón-Garcidueñas differs from this research because densely industrialized districts do not have a high F06.8 incidence. The difference results may be caused by not all industries in Surabaya produce air pollutants. Research is needed on the noise, liquid, and solid pollution impact on the incidence of F06.8.

4) Moderate depressive disorder (F32.1) mostly occurred in Gubeng, Sawahan, and Tambaksari Districts. In this research, F32.1 was included in the highest incidence of disease with 75 out of 1,314 incidents $(7.8 \%)$. This is supported by research in German asylum seeker camps that F32.1 is among the highest incidence of disease with 14 out of 158 incidents (8.9\%) [9]. The research result by Heflin and Iceland using the cohort method shows that poverty affects the depression incidence [10]. The research result by Heflin and Iceland differs from this research because districts with a high number of poor households also did not have high F32.1 incidences. The results difference may be due to differences in research methods.

5) MMR (F70) mostly occurred in Kenjeran, Tambaksari, and Semampir Districts. In this research, F70 was included in the ten most diseases with $6.9 \%$ incidence. This is supported by Ceballos, et al. that F70 is included in the ten most diseases in Brazilian psychosocial care with 5\% incidence [11]. In this research, districts with high levels of poor households do not have a F70 high incidence. This result difference from the study result of Gopalan, et al. that low socioeconomic conditions in India can increase the risk of mild and severe MR [12]. The difference in results may be due to differences in poverty lines in the two countries.

6) ADHD, predominantly inattentive type (F90.0) mostly occurred in Sawahan, Tambaksari, Gubeng, and Semampir Districts. In this research, F90.0 was included in the ten most diseases with 91 of 1,134 incidents (6.9\%). Besides, compared to the other F90 (hyperkinetic disorders) subtype, F90.0 is the most common subtype. This is supported by Garbe, et al. stated that F90.0 subtype that occurs the most (79.1\%) [13]. Furthermore, the three districts with the highest F90.0 incidence have high population numbers. Risk factors for ADHD include maternal smoking and low socioeconomic conditions [14]. Further research is needed to determine the smoking and parenting impact on the ADHD incidence in Surabaya.

7) Hebephrenic schizophrenia (F20.1) mostly occurred in Tambaksari, Sawahan, and Krembangan Districts. Research at the Pontianak hospital shows that hebephrenic schizophrenia is the second most common type of schizophrenia (1.3\%) after the incidents of paranoid schizophrenia[6]. Similar to this study, code F20.1 was included in the ten most diseases with 68 incidents (5.2\%). Apart from environmental factors, schizophrenia can also be influenced by genetic factors in various districts in Surabaya, so further research is needed regarding genetic factors for the incidence of code F20.1 in Surabaya.

8) Other stressful life events affecting family and 
household (Z63.7) mostly occurred in Tambaksari, Krembangan, Semampir, Sawahan, Simokerto, Pabean Cantian, Wonokromo, Sukomanunggal, and Kenjeran Districts. In this research, the districts with the Z63.7 highest incidence had the poor households' highest number, except for Kenjeran and Sukomanunggal. This is supported by research conducted in the UK, that poverty can cause stress and will cause tension in the household [15]. Besides, districts with a high Z63.7 incidence may also be influenced by the partner's personality and harmony in the household which needs further research.

9) Atypical autism (F84.1) mostly occurred in Sukomanunggal, Semampir, Gubeng, Tambaksari, and Rungkut Districts. Atypical autism is another name for Pervasive Developmental Disorder Not Otherwise Specified (PDD-NOS)[16]. Research conducted by Lazoff, et al. showed that PDD-NOS is the most common Autism Spectrum Disorder (ASD) subtype [17]. Similar to this research, F84.1 is the F84 subtype (ASD) that occurs more frequently than other subtypes. Further research is needed regarding genetic factors for the incidence of code F84.1 in Surabaya.

10) MADD (F41.2) mostly occurred in Tambaksari, Sawahan, and Gubeng Districts. In this research, F41.2 was included in the ten most diseases with 102 of 1,314 incidents (3.5\%). This is supported by research in a Nepalese prison hospital whose F41.2 is one of the ten most diseases with 5 of 121 inmates (41.2\%) [8]. However, the three districts with the highest F41.2 incidence are not districts with the highest number of industries. This is different from the research of Pun, et al. that industrial air pollutants influence the symptoms' occurrence of anxiety and depression [18]. The result differences may be caused by not all industries in Surabaya produce air pollutants. Further research is needed regarding the pollutants' impact on the F41.2 incidence in Surabaya.

Distribution of disease incidence based on five regions in Surabaya

1) Psychiatric examinations related to education and literacy problems (Z55) and psychiatric examinations related to other education and literacy problems (Z55.8) mostly occurred in North Surabaya, East Surabaya, and South Surabaya. In this research, the three regions with the highest incidence of Z55 and Z55.8 had the highest number of poor household. This research results are supported by Van der Berg's that in developing countries access to education is determined by the family economy [19]. The lower the family economy, the more it limits access to education for children.

2) Paranoid schizophrenia (F20.0) and paranoid schizophrenia, partial remission (F20.04) mostly occurred in East Surabaya, South Surabaya, and North Surabaya. In this research, the paranoid schizophrenia incidence was more prevalent than other schizophrenia subtypes in five Surabaya areas. This is supported by Sira, et al. [6]. Schizophrenia can be caused by an interaction between genetic factors and prolonged childhood trauma, which manifests in adulthood. Childhood trauma can take the form of physical abuse or sexual violence [20]. Further research is needed regarding genetic factors and violence in children against the schizophrenia incidence in Surabaya.

3) Other specified mental disorders due to known physiological condition (F06.8) mostly occurred in South Surabaya, North Surabaya, and East Surabaya. Industry may increase the occurrence of air pollution, such as industries of coal processing, petroleum, and chemicals. In this research, this type of industry occurred in three regions with the highest F06.8 incidence. This is supported by Block and Calderón-Garcidueñas [3]. Densely industrialized districts can produce a lot of air pollutants. Air pollutants can enter the respiratory tract then particles such as ozone and nitrogen dioxide enter the blood vessels, causing inflammation and oxidative stress that leads to neuron damage [21].

4) Moderate depressive disorder (F32.1) mostly occurred in East Surabaya, South Surabaya, and North Surabaya. In this research, the three regions with the highest incidence of code F32.1 had the highest number of poor household. This research results are supported by the research of Heflin and Iceland, that an environment with high poverty rates can cause long-term stress that can 
lead to depression [10].

5) MMR (F70) mostly occurred in North Surabaya, Central Surabaya, and West Surabaya. In this research, North Surabaya had the poor household highest number, while Central Surabaya and West Surabaya had the poor household lowest number in Surabaya. This is different from Gopalan, et al. [12]. The result differences can be caused by a large number of industries in West Surabaya and the dense population in Central Surabaya. Both can affect the occurrence of code F70.

6) ADHD, predominantly inattentive type (F90.0) mostly occurred in South Surabaya, East Surabaya, Central Surabaya, and North Surabaya. In this research, four regions with the largest F90.0 incidents also had a poor household highest number. This is supported by Russell, et al. that poverty can lead to ADHD's occurrence [22]. Poor socioeconomic conditions make a person unable to meet their daily needs, which can increase the risk of ADHD.

7) Hebephrenic schizophrenia (F20.1) mostly occurred in East Surabaya, South Surabaya, and North Surabaya. In this research, the three regions with the highest F20.1 incidents also had a poor household highest number. This is supported by Lee, et al. that schizophrenia is more common in people living in low-income areas[23]. Other factors are densely populated housing, malnutrition, and social inequality [24]. Research is needed on malnutrition and social disparities in Surabaya.

8) Other stressful life events affecting family and household (Z63.7) mostly occurred in South Surabaya, North Surabaya, and West Surabaya. In this study, North Surabaya, and South Surabaya had the poor household's highest number but West Surabaya had the poor household's lowest number in Surabaya. This is different from Corlyon, et al. [15]. The result differences can be caused by the number of industries in West Surabaya. Thomson states that prolonged stress is one of the body's responses that occurs due to exposure to air pollutants [25].

9) Atypical autism (F84.1) mostly occurred in East Surabaya and West Surabaya. In this research, F84.1 had the highest incidence of disease (4.8\%) than the other
F84 subtypes. This is different from the research of Hofer, et al. in Germany that F84.1 is the subtype with the least occurrences [26]. The result differences may be due to different mental illness programs detection in developed and developing countries. The low rate of other mental disorders may be due to the difficulty in obtaining the autism spectrum prevalence from health data for children with special needs in developing countries [27]. Further research is needed on the health data of children with special needs in Surabaya.

10) MADD (F41.2) mostly occurred in East Surabaya, South Surabaya, West Surabaya, and North Surabaya. In this research, the four regions with the highest F41.2 incidence had the largest number of industries. This is supported by Pun, et al. that air pollutants play a role in anxiety disorders and depression [18]. Industrial air pollutants influence the onset of symptoms and depression through inflammatory reactions and oxidative stress and the greatest influence is found in research subjects with lower socioeconomic conditions $[3,18]$.

The results of the chi-square test show the pvalue of 0.000 and the relationship is said to be significant if the value is smaller than the value of $\alpha$ (0.05). This shows that the results of this study are that there is a significant relationship between residence and the incidence of the ten most diseases in the psychiatric clinic of Dr. Soetomo. This is in line with research conducted by Vicente, et al. that there is a significant difference in the prevalence of mental illnesses found in different areas of residence in Chile [28]. The residence is one of the important factors affecting the mental health conditions of its inhabitants.

Research limitation

The limitation of this research is the limited socio-demographic data sources in the district of Surabaya City. Besides, there is still a lack of previous research on the relationship between mental disorders and residence that researchers can find from Indonesia and international journals. The limitation from medical record data such as there is 1 medical record that is not listed where the patient residence.

\section{Conclusion}


The results of this research found that there was a significant relationship (goodness of fit) between residence and ten most diseases in Dr. Soetomo hospital psychiatric clinic July 2017 - June 2019 who resides in Surabaya.

\section{Acknowledgments}

Thanks to Prof. H. Dr. Budi Santoso, dr., Sp.OG $(\mathrm{K})$ as dean of faculty of medicine, Dr. Joni Wahyuhadi, dr., Sp.BS (K) as director of the Dr. Soetomo hospital, Khairina, dr. Sp.KJ (K) as the main supervisor, Dr. Budi Utomo, dr. M.Kes and Nining Febriyana, dr. Sp.KJ (K) as the second supervisor. The results of this research must be explained properly so as not to cause misunderstandings about the relationship between residence and mental disorders.

\section{References}

[1] WHO, "Mental disorders," Nov. 2019. .

[2] K. Riskesdas, "Hasil Utama Riset Kesehata Dasar (RISKESDAS)," J. Phys. A Math. Theor., vol. 44, no. 8, pp. 1-200, 2018, doi: 10.1088/1751$8113 / 44 / 8 / 085201$.

[3] M. L. Block and L. Calderón-Garcidueñas, "Air pollution: mechanisms of neuroinflammation and CNS disease," Trends Neurosci., vol. 32, no. 9, pp. 506-516, Sep. 2009, doi: 10.1016/j.tins.2009.05.009.

[4] S. A. Ogston, S. Lemeshow, D. W. Hosmer, J. Klar, and S. K. Lwanga, "Adequacy of Sample Size in Health Studies.," Biometrics, vol. 47, no. 1, p. 347, 1991, doi: 10.2307/2532527.

[5] R. A. Carr-Hill, International Literacy Statistics: A Review of Concepts, Methodology and Current Data. UNESCO Institute for Statistics, 2008.

[6] I. Sira, J. Tarigan, and A. Rialita, "KARAKTERISTIK SKIZOFRENIA DI RUMAH SAKIT KHUSUS ALIANYANG PONTIANAK PERIODE 1 JANUARI-31 DESEMBER 2009," Aug. 2013.

[7] C. J. Carter, "Schizophrenia: A Pathogenetic Autoimmune Disease Caused by Viruses and Pathogens and Dependent on Genes," J. Pathog., vol. 2011, pp. 1-37, 2011, doi: $10.4061 / 2011 / 128318$.

[8] P. Bhattarai, V. D. Sharma, M. Chapagai, and P. Tulachan, "Prevalence of psychiatric morbidity among prisoners attending OPD of Central Jail Hospital, Kathmandu," J. Psychiatr. Assoc. Nepal, vol. 7, no. 1, pp. 24-31, 2018, doi: 10.3126/jpan.v7i1.22934.

[9] K. Richter, L. Peter, H. Lehfeld, H. Zäske, S. Brar-Reissinger, and G. Niklewski, "Prevalence of psychiatric diagnoses in asylum seekers with follow-up," BMC Psychiatry, vol. 18, no. 1, pp. 1-7, 2018, doi: 10.1186/s12888-018-1783-y.

[10] C. M. Heflin and J. Iceland, "Poverty, material hardship, and depression," Soc. Sci. Q., vol. 90, no. 5, pp. 1051-1071, Dec. 2009, doi: 10.1111/j.1540-6237.2009.00645.x.

[11] G. Y. Ceballos, C. S. Paula, E. L. Ribeiro, and D. N. Santos, "Child and adolescent psychosocial care center service use profile in Brazil: 2008 to 2012," Rev. Bras. Psiquiatr., vol. 41, no. 2, pp. 138-147, 2019, doi: 10.1590/1516-4446-20180011.

[12] R. T. Gopalan, R. Sharma, and M. P. Unnikrishnan, "View of Socio-Demographic and Clinical Features of Children with Intellectual Disability and Their Parents-an Indian Study," Int. Neuropsychiatr. Dis. J. , vol. 2, pp. 289-302, 2014.

[13] E. Garbe et al., "Drug treatment patterns of attention-deficit/hyperactivity disorder in children and adolescents in germany: Results from a large population-based cohort study," J. Child Adolesc. Psychopharmacol., vol. 22, no. 6, pp. 452-458, 2012, doi: 10.1089/cap.2012.0022.

[14] K. Langley, P. A. Holmans, M. B. M. van den Bree, and A. Thapar, "Effects of low birth weight, maternal smoking in pregnancy and social class on the phenotypic manifestation of Attention Deficit Hyperactivity Disorder and associated antisocial behaviour: Investigation in a clinical sample," BMC Psychiatry, vol. 7, pp. 1-8, 2007, doi: 10.1186/1471-244X-7-26.

[15] J. Corlyon, L. Stock, C. Castellanos Serrano, and M. Gieve, "Reducing Poverty in the UK: A Collection of Evidence Reviews," no. August, pp. 1-176, 2014.

[16] O. Ousley and T. Cermak, "Autism Spectrum Disorder: Defining Dimensions and Subgroups," Curr. Dev. Disord. Reports, vol. 1, no. 1, pp. 2028, 2014, doi: 10.1007/s40474-013-0003-1.

[17] T. Lazoff, L. Zhong, T. Piperni, and E. Fombonne, "Prevalence of Pervasive Developmental Disorders Among Children at the English Montreal School Board," 2010.

[18] V. C. Pun, J. Manjourides, and H. Suh, "Association of ambient air pollution with depressive and anxiety symptoms in older adults: Results from the NSHAP study," Environ. Health Perspect., vol. 125, no. 3, pp. 342-348, 2017, doi: 10.1289/EHP494.

[19] S. van der Berg, "Preface Education Policy Series," 2008.

[20] C. Morgan and H. Fisher, "Environment and schizophrenia: Environmental factors in schizophrenia: Childhood trauma - A critical review," Schizophr. Bull., vol. 33, no. 1, pp. 3-10, 2007, doi: 10.1093/schbul/sbl053. 
[21] The Lancet Neurology, "Air pollution and brain health: an emerging issue," Lancet Neurol., vol. 17 , no. 2 , p. 103 , 2018, doi: 10.1016/S14744422(17)30462-3.

[22] G. Russell, T. Ford, R. Rosenberg, and S. Kelly, "The Association Between Socioeconomic Disadvantage and Attention Deficit/Hyperactivity Disorder (ADHD): A Systematic Review ,"Feb. 2016.

[23] C. Te Lee et al., "Relationship between Schizophrenia and Low-Income Based on Age and Sex: Results from a Nation-wide PopulationBased Longitudinal Study," Neuropsychiatry (London)., vol. 08, no. 03, pp. 1000-1006, 2018, doi: 10.4172/neuropsychiatry.1000426.

[24] J. K. Burns, A. Tomita, and A. S. Kapadia, "Income inequality and schizophrenia: Increased schizophrenia incidence in countries with high levels of income inequality," Int. J. Soc.
Psychiatry, vol. 60, no. 2, pp. 185-196, Mar. 2014, doi: 10.1177/0020764013481426.

[25] E. M. Thomson, "Air Pollution, Stress, and Allostatic Load: Linking Systemic and Central Nervous System Impacts," J. Alzheimer's Dis., vol. 69, no. 3, pp. 597-614, 2019, doi: 10.3233/JAD-190015.

[26] J. Höfer et al., "Complementary and alternative medicine use in adults with autism spectrum disorder in Germany: results from a multi-center survey," doi: 10.1186/s12888-019-2043-5.

[27] S. A. Samadi and R. McConkey, "Autism in Developing Countries: Lessons from Iran," Autism Res. Treat., vol. 2011, pp. 1-11, 2011, doi: $10.1155 / 2011 / 145359$.

[28] B. Vicente et al., "Regional differences in psychiatric disorders in Chile," Soc. Psychiatry Psychiatr. Epidemiol., vol. 41, no. 12, pp. 935942, 2006, doi: 10.1007/s00127-006-0124-5. 